\title{
Microencapsulation of Probiotic Lactobacillus helveticus with Different Wall Materials by Spray Drying
}

\author{
Najara Pinto Ribeiro Barro ${ }^{1(\mathbb{D})}$, Leonardo Meirelles da Silva ${ }^{1(\mathbb{D})}$, Guilherme de Souza Hassemer ${ }^{1(\mathbb{D})}$,

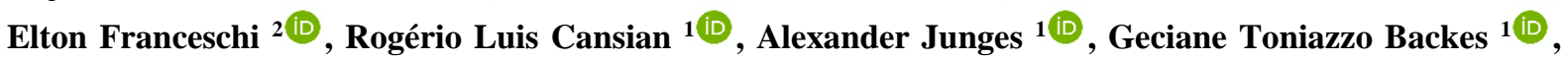 \\ Jamile Zeni $^{1}{ }^{(D)}$, Rosicler Colet ${ }^{1}$ (D), Marcelo Mignoni ${ }^{1}$ (D), Eunice Valduga ${ }^{1, *}$ (D) \\ 1 Department of Food Engineering, URI -Erechim Av. Sete de Setembro, 1621, Erechim, Rio Grande do Sul, Brazil, 99709 - \\ 910, Brazil \\ 2 Center for Research on Colloidal Systems (NUESC), Institute of Research and Technology (ITP), Tiradentes University \\ (UNIT), Aracaju, SE 49032-490, Brazil \\ * Correspondence: veunice@ uricer.edu.br;
}

Scopus Author ID 23490413300

Received: 6.11.2020; Revised: 4.12.2020; Accepted: 7.12.2020; Published: 10.12.2020

\begin{abstract}
The present study seeks to evaluate different matrixes (chitosan, gelatin - bloom 189, gelatin - bloom 246, gum Arabic, and maltodextrin) to encapsulate Lactobacillus helveticus (LH 091), as well as optimal spray-drying conditions. L. helveticus displayed a survival rate close to $89 \%$, with their viability above the minimum level of $10^{7} \mathrm{CFU} / \mathrm{g}$ at point of delivery, after microencapsulation in a gum Arabic-maltodextrin (1:1) matrix followed by spray-drying (air in at 70 to $80^{\circ} \mathrm{C}$, a feed rate of $0.09 \mathrm{~mL} / \mathrm{min}$, and a pressure of $0.10 \mathrm{bar}$ ). Microcapsules containing probiotic displayed a water activity of 0.494 , rounded edges and an average size of $2.6 \mu \mathrm{m}$. The differential scanning calorimetry and thermogravimetry pointed to the thermal stability of the microparticles with encapsulated probiotics. These favorable properties of the probiotic microparticles make them suitable for incorporation into functional food.
\end{abstract}

Keywords: Lactobacillus helveticus; gum Arabic; maltodextrin; atomization; microencapsulation.

(C) 2020 by the authors. This article is an open-access article distributed under the terms and conditions of the Creative Commons Attribution (CC BY) license (https://creativecommons.org/licenses/by/4.0/).

\section{Introduction}

Probiotics are live microorganisms that offer their host various health benefits by maintaining normal intestinal microbiota, inhibiting the adhesion of pathogenic bacteria to the intestinal mucosa, increasing immunity, and lowering cholesterol levels [1-6]. The two genera most commonly used as probiotic microorganisms are Bifidobacterium sp. and Lactobacillus sp [2,6-11]. However, providing and maintaining the required minimum amount of viable probiotic cells to confer any positive health effects $\left(10^{6}\right.$ to $10^{7} \mathrm{CFU} / \mathrm{g}$ at a point of delivery) is a great challenge, considering their sensitivity to processing, storage, and shipping. Furthermore, incorporating live probiotic microorganisms into food products also has issues, mostly due to the probiotic's susceptibility to several factors, such as temperature, oxygen, water activity, and osmotic pressure mechanical stress, $\mathrm{pH}$ value, etc. [12,13].

Spray-drying is the most potential method, mainly to modify the conditions during spray drying to control both size and shape of the particle. Microencapsulation is a promising method for protecting probiotic cells against the adverse conditions they may face [11-14]. Among many microencapsulation techniques, spray drying is one of the most interesting due to its low costs, large scale potential, high probiotic stability, and low amounts of cellular 
degradation during drying if the drying process and formulation parameters have been optimized correctly $[15,16]$. However, during the spray-drying process, probiotic cells are subjected to heat and dehydration, which might damage the cell's membrane or, in extreme cases, completely inactivate the probiotic's culture. However, this might be controlled by adjusting the drying process' parameters like outlet temperature, feed rate, inlet temperature, drying time [17], and the drying medium.

The use of carbohydrates with high activation energy helps to prevent thermal and oxidative stresses during storage. Among them, maltodextrin is widely used as a coating material due to its non-toxicity, low cost, good solubility, low viscosity even at high solid content, and availability [18]. Furthermore, maltodextrin moderately acts as a prebiotic. Its low emulsifying capacity is preferred only in combination with other carrier agents such as gum Arabic [19,20]. Gum Arabic is a dried exudate obtained from Acacia senegal (L.). It consists mainly of higher molecular weight polysaccharides and its salts. When subjected to hydrolysis, it yields arabinose, galactose, rhamnose, and glucuronic acid. At levels of 1 to $10 \%$, gum Arabic acts as a film former, moisture stabilizer, and mouth-feel enhancer [21]. Apart from this, gum Arabic prevents complete dehydration of cell components and stabilizes bacterial cells during drying and storage [22,23].

Lactobacillus helveticus is generally recognized as safe (GRAS). It is used as a starter culture in manufacturing semi-hard cheeses, fermented milk products, or food additives because of its potential antihypertensive effect [24,25]. However rare are the studies in the literature that evaluated the encapsulation of L. helveticus. The present study evaluates different wall materials in the probiotic encapsulation by spray-drying and the formed microcapsules' characterization.

\section{Materials and Methods}

\subsection{Probiotics preparation.}

A freeze-dried strain of Lactobacillus helveticus (LH 091) 1 was obtained from SACCO Brasil (Campinas, São Paulo, Brazil). To prepare the probiotic culture, different assays were performed to obtain a solution of $10^{8}-10^{9} \mathrm{CFU}$ [26]. Each of the assays was performed as follows:

- Assay 1: Inoculum preparation was performed by adapting what has been described by Silva et al. [27]. To do this, the freeze-dried bacterial strain was reactivated in $10 \mathrm{~mL}$ of Luria-Betani (LB) broth, incubated in an anaerobic jar for $24 \mathrm{~h}$ at $35^{\circ} \mathrm{C} \pm 1^{\circ} \mathrm{C}$. After the incubation period, $10 \mathrm{~mL}$ of the culture were added to $90 \mathrm{~mL}$ of LB broth and incubated once again at $35^{\circ} \mathrm{C} \pm 1^{\circ} \mathrm{C}$ for $24 \mathrm{~h}$. Further activation was then performed by adding $100 \mathrm{~mL}$ of the inoculum in $500 \mathrm{~mL}$ of $\mathrm{LB}$ broth and incubating the solution at $35^{\circ} \mathrm{C} \pm 1^{\circ} \mathrm{C}$ for $24 \mathrm{~h}$ in an anaerobic jar. The culture was then centrifuged (MeD Instrumentos - MPW 351R) at $7000 \mathrm{rpm}$ for $5 \mathrm{~min}$ at $5^{\circ} \mathrm{C}$. Centrifuged cells were washed twice with a $2 \%$ sodium citrate solution and then resuspended in $10 \mathrm{~mL}$ of sodium citrate $(2 \%)$. This solution was then used to determine the amount of the culture's viable cells.

- Assay 2: This assay followed the same procedures described in Assay 1; however, this time, samples were incubated in an anaerobic jar for $48 \mathrm{~h}$ at $35^{\circ} \mathrm{C} \pm 1^{\circ} \mathrm{C}$.

- Assay 3: In this assay, $1 \mathrm{~g}$ of the freeze-dried strain was added to $10 \mathrm{~mL}$ of $\mathrm{LB}$ broth and incubated in an anaerobic jar for $48 \mathrm{~h}$ at $35^{\circ} \mathrm{C} \pm 1^{\circ} \mathrm{C}$. After the incubation period, $10 \mathrm{~mL}$ of the culture were added to $100 \mathrm{~mL}$ of $\mathrm{LB}$ broth (final volume of $110 \mathrm{~mL}$ ) and once again 
incubated for $48 \mathrm{~h}$ at $35^{\circ} \mathrm{C} \pm 1^{\circ} \mathrm{C}$. Following incubation, the $110 \mathrm{~mL}$ of culture were seeded in 2 flasks containing $500 \mathrm{~mL}$ of LB broth (total volume of $1.1 \mathrm{~L}$ ) and were incubated again in an anaerobic jar for $48 \mathrm{~h}$ at $35^{\circ} \mathrm{C} \pm 1^{\circ} \mathrm{C}$. The cultures were then centrifuged at $5^{\circ} \mathrm{C}, 7000 \mathrm{rpm}$ for 10 min. Cells were washed twice with a $2 \%$ sodium citrate solution and then resuspended in $7 \mathrm{~mL}$ of sodium citrate $2 \%$.

- Assay 4: This assay followed the same procedures of Assay 3; however, the initial strain reactivation procedure was performed by adding $1 \mathrm{~g}$ of freeze-dried cells to $10 \mathrm{~mL}$ of de Man, Rogosa and Sharpe (MRS) broth and incubating at $35^{\circ} \mathrm{C} \pm 1^{\circ} \mathrm{C}$ for $60 \mathrm{~h}$ in an anaerobic jar. The solution was then transferred to $100 \mathrm{~mL}$ of MRS broth (total volume of $110 \mathrm{~mL}$ ) and incubated at $35^{\circ} \mathrm{C} \pm 1^{\circ} \mathrm{C}$ for $60 \mathrm{~h}$.

- Assay 5: During this assay, $1 \mathrm{~g}$ of freeze-dried cells were reactivated in $10 \mathrm{~mL}$ of MRS broth, incubated in an anaerobic jar at $37^{\circ} \mathrm{C} \pm 1^{\circ} \mathrm{C}$ for $48 \mathrm{~h}$. The culture was then centrifuged at $5^{\circ} \mathrm{C}, 4000 \mathrm{rpm}$ for $15 \mathrm{~min}$, washed with peptone water and suspended in $10 \mathrm{~mL}$ of MRS broth. The cell suspension was then used to produce more biomass, with samples of $0.1 \mathrm{~mL}$ taken every $48 \mathrm{~h}$ to be inoculated in $10 \mathrm{~mL}$ of MRS Broth, with the previous culture being centrifuged at $4000 \mathrm{rpm}$, for $15 \mathrm{~min}$ at $5^{\circ} \mathrm{C}$, washed with peptone water, resuspended in $10 \mathrm{~mL}$ of RMS both and then submitted to the counting of viable cells.

- Assay 6: The freeze-dried strain $(1 \mathrm{~g})$ as reactivated in $10 \mathrm{~mL}$ of MRS broth, followed by dilution and counting of viable cells.

\subsection{Preparation of the encapsulating matrix.}

The polymers to be used as the encapsulation matrix were obtained from different retailers. Gum Arabic was obtained from Dinâmica Química Contemporânea (São Paulo, Brasil); maltodextrin and starch came from Ingredion (Mogi Guaçu, Brasil); gelatin was produced by Gelnex (Itá, Brasil); chitosan and trehalose were acquired from Purifarma (São Paulo, Brazil). Different treatments were conducted using these materials, seeking to determine the best encapsulating matrix:

- Treatment 1: Chitosan (100\%);

- Treatment 2: Gelatin, 189 bloom (100\%);

- Treatment 3: Gelatin, 246 bloom (100\%);

- Treatment 4: Gum Arabic (100\%);

- Treatment 5: Maltodextrin (100\%);

- Treatment 6: Maltodextrin (70\%), gum Arabic (30\%);

- Treatment 7: Maltodextrin (60\%), gum Arabic (40\%);

- Treatment 8: Maltodextrin (50\%), gum Arabic (50\%).

All matrixes (Treatments 1 to 8) were tested using commercial white chocolate. After melting and retempering, the encapsulating agent was added in concentrations of 3,5, and 7\% $(\mathrm{m} / \mathrm{m})$. The chocolate molding was done in an acrylic container, which was then cooled at $5^{\circ} \mathrm{C}$ $-7^{\circ} \mathrm{C}$ for $20 \mathrm{~min}$. The chocolate bars were wrapped in tinfoil and stored at $20^{\circ} \mathrm{C}$ for 7 days, allowing for stable $\beta$ crystals.

The samples were submitted to sensory analysis, where $10 \mathrm{~g}$ of chocolate samples were offered to non-trained tasters $(n=25)$, in plastic containers coded by three-digit numbers, alongside an evaluation sheet for global impression (acceptability) - Hedonic scale test, 9point-structured scale ( 1 - Dislike extremely; 9 - Like extremely), according to the methods described by Dutcosk [28]. In between samples, the tasters used room temperature mineral water and a cracker to clean their palate. 
Before the sensory analysis took place, the project was submitted to the ethics committee approval, registered as 01804818.3.0000.5351. Participants also signed a consent form. They declare that they willingly chose to participate in the sensory evaluation and allow the test results to be published.

\subsection{Encapsulation and spray-drying.}

Before the spray-drying process started, the drying apparatus (SD05, Lab Plant) was sanitized using ultrapure water at $150^{\circ} \mathrm{C}$ for $10 \mathrm{~min}$. The equipment's needle was also sanitized by being immersed in a $70 \%$ ethanol solution for $30 \mathrm{~min}$. Initial probiotic encapsulation tests (Assays 1, 2, 3, 4, and 5) were performed using $24 \mathrm{~g}$ of encapsulating matrix. The matrix was hydrated with $100 \mathrm{~mL}$ of sodium phosphate buffer $(\mathrm{pH} 7.0)$ for $2 \mathrm{~h}$ under magnetic stirring. After the hydration period, $1 \mathrm{~g}$ of probiotic cells $\left(10^{8}-10^{9} \mathrm{CFU} / \mathrm{g}\right)$ were added to the matrix and stirred for $10 \mathrm{~min}$. The solution containing the matrix, probiotic cells, and the buffer was pumped (pneumatic injector orifice diameter of $0.5 \mathrm{~mm}$ ) at a flow rate of $0.09 \mathrm{~mL} / \mathrm{min}$, a pressure of $0.08-0.12$ bar, and drying chamber inlet temperatures of $70,80,90,100$, and $110^{\circ} \mathrm{C}$.

When using the freeze-dried microorganism (Assay 6), the same concentration of encapsulating agent and hydration conditions previously described was used. After the matrix's hydration, different amounts of freeze-dried probiotic cells were added $(4,5,9$, and $18 \mathrm{~g})$. The probiotic/matrix/buffer solution was stirred for $10 \mathrm{~min}$ before being spray-dried under the same conditions as previously described.

The microcapsules from the spray-drying process were evaluated regarding the number of probiotic cells, water activity, moisture, and, for the maximized parameters, morphology (scanning electron microscopy), thermogravimetric analysis (TG), and differential scanning calorimetry (DSC).

\subsection{Analytical determinations.}

\subsubsection{Water activity (Aw).}

Water activity determination was performed in Aqualad CX-2 Water Activity - System. The system was calibrated using distilled water and a $\mathrm{NaCl}$ solution $(0.819 \mathrm{aw})$. After the system stabilized, readings of $\mathrm{aw} / \mathrm{T}^{\circ} \mathrm{C}$ of the samples were performed.

\subsubsection{Moisture.}

The samples' moisture was determined via infra-red drying in a Mettler LTJ (Brazil) apparatus.

\subsubsection{Differential scanning calorimetry (DSC).}

The microcapsules were analyzed in a DSC-60 (Shimadzu, Kyoto, Japan). Samples of approximately $5 \mathrm{mg}$ were placed in sealed aluminum pans and submitted to a temperature cycle of 30 to $300^{\circ} \mathrm{C}$ (rate of $10^{\circ} \mathrm{C} / \mathrm{min}$ ) under a nitrogen atmosphere $(150 \mathrm{~mL} / \mathrm{min})$. 


\subsubsection{Thermogravimetric analysis (TGA).}

TGA analysis was performed in a DTG-60 (Shimadzu, Kyoto, Japan). Samples of approximately $7 \mathrm{mg}$ underwent a temperature cycle of 20 to $300^{\circ} \mathrm{C}$ at a rate of $10^{\circ} \mathrm{C} / \mathrm{min}$, under a nitrogen atmosphere $(100 \mathrm{~mL} / \mathrm{min})$.

\subsubsection{Scanning electron microscopy (SEM).}

The encapsulated samples' morphology was analyzed by scanning electron microscopy (SEM) technique using a ZEISS/EVO LS 25 model microscope (ZEISS instrument, Germany) with a magnification of $107,5,000$, and 10,000 times and a voltage of $10 \mathrm{kV}$. The samples were fixed on metallic support, using double-sided carbon adhesive tape, and covered with a thin layer of gold under vacuum. Particle size was measured by the Size Meter software (version 1.1) using at least 50 particles for each experiment. In contrast, the software Statistica ${ }^{\circledR} 5.0$ was used to calculate the particle size distribution.

\subsection{Statistical evaluation.}

The results $(n=3)$ were statistically treated via analysis of variance (ANOVA), with means being compared by Tukey test and/or Student's t-test $(\mathrm{p}<0.05)$, using the software STATISTICA 7.0 (Statsoft Inc, USA).

\section{Results and Discussion}

\subsection{Encapsulating matrix.}

Table 1 shows the treatments performed with different encapsulating matrixes and different concentrations $(3,5$, and $7 \%)$ in commercial white chocolate samples and the mean score given by the sensory evaluating panel using the 9-point hedonic scale.

Table 1. Mean scores of white chocolate samples were added with 3, 5, and 7\% of each encapsulating matrix.

\begin{tabular}{l|c|c|c}
\multirow{2}{*}{ Encapsulating matrix } & \multicolumn{3}{|c}{ Taster's score } \\
\cline { 2 - 4 } & $\mathbf{3 \%}$ & $\mathbf{5 \%}$ & $\mathbf{7 \%}$ \\
\hline Treatment 1 - Chitosan (100\%) & $7.2^{\mathrm{cA}}$ & $7.0^{\mathrm{cA}}$ & $6.5^{\mathrm{dB}}$ \\
\hline Treatment 2 - Gelatin 189 bloom (100\%) & $6.5^{\mathrm{dA}}$ & $6.0^{\mathrm{bB}}$ & $5.8^{\mathrm{eB}}$ \\
\hline Treatment 3 - Gelatina 246 bloom (100\%) & $6.7^{\mathrm{dA}}$ & $6.2^{\mathrm{bcB}}$ & $6.0^{\mathrm{eB}}$ \\
\hline Treatment 4 - Gum Arabic (100\%) & $8.0^{\mathrm{bA}}$ & $8.0^{\mathrm{bA}}$ & $6.8^{\mathrm{cB}}$ \\
\hline Treatment 5 - Maltodextrin (100\%) & $8.2^{\mathrm{abA}}$ & $8.0^{\mathrm{bB}}$ & $7.2^{\mathrm{bC}}$ \\
\hline Treatment 6 - Maltodextrin (70\%), gum Arabic $(30 \%)$ & $8.0^{\mathrm{bA}}$ & $7.9^{\mathrm{bA}}$ & $6.5^{\mathrm{dB}}$ \\
\hline Treatment 7 - Maltodextrin (60\%), gum Arabic $(40 \%)$ & $7.6^{\mathrm{bcA}}$ & $7.5^{\mathrm{cA}}$ & $7.0^{\mathrm{bcB}}$ \\
\hline Treatment 8 - Maltodextrin (50\%), gum Arabic (50\%) & $8.6^{\mathrm{aA}}$ & $8.5^{\mathrm{aA}}$ & $8.1^{\mathrm{aB}}$
\end{tabular}

*Means followed by identical lowercase/uppercase letters in lines/rows indicate no significant difference at $95 \%$ confidence level (Tukey test, $\mathrm{p}<0.05$ ). Hedonic scale: 1 - dislike extremely; 9 - like extremely.

Chitosan (Treatment 1) and gelatin (Treatments 2 and 3) displayed a negative influence $(p<0.05)$ on the chocolate sample's global evaluation. It was observed that these treatments also altered the chocolate's color, and some panelists described the samples as having a grainy texture, akin to sand.

Gum Arabic (Treatment 4) and maltodextrin (Treatment 5) behaved similarly, with no major changes on the sample's overall acceptability $(p>0.05)$. Concentrations of 3 and $5 \%$ $(\mathrm{m} / \mathrm{m})$ of encapsulating agents were the ones to cause the lowest amount of changes in the sample's overall evaluation by the panelists. 
Based on the data found during these initial tests, the encapsulating matrix composed of 50\% gum Arabic and 50\% maltodextrin (Treatment 8 ) was chosen to be used in further spray-drying encapsulation assays in a concentration of $5 \%(\mathrm{~m} / \mathrm{m})$.

\subsection{Encapsulation efficiency of spray-dried probiotic powder.}

Table 2 lists the different drying temperatures and the probiotic's viability after being encapsulated in a gum Arabic-maltodextrin (1:1) matrix. The highest survivability rates for $L$. helveticus were observed at temperatures of 70 and $80^{\circ} \mathrm{C}(88.93 \%$ and $66.7 \%$, respectively). However, microcapsules that have been dried at temperatures above $80^{\circ} \mathrm{C}$ do not provide the minimum necessary amount of viable probiotic cells to successfully affect the host $\left(10^{7} \mathrm{CFU} / \mathrm{g}\right.$ at a point of delivery) [26].

Table 2. Spray-drying temperatures and cellular viability of probiotic cells encapsulated in a gum Arabicmaltodextrin matrix $(1: 1)$

\begin{tabular}{c|c|c|c|c}
$\begin{array}{c}\text { Air inlet } \\
\text { temperature } \\
\left({ }^{\mathbf{0}} \mathbf{C}\right)\end{array}$ & $\begin{array}{c}\text { Air outlet } \\
\text { temperature } \\
\left({ }^{\mathbf{0}} \mathbf{C}\right)\end{array}$ & $\begin{array}{c}\text { Cell count before } \\
\text { drying } \\
(\mathbf{l o g} \mathbf{C F U} / \mathbf{g})\end{array}$ & $\begin{array}{c}\text { Cell count after } \\
\text { drying } \\
(\log \mathbf{C F U} / \mathbf{g})\end{array}$ & $\begin{array}{c}\text { Survivability rate } \\
(\mathbf{\%})^{*}\end{array}$ \\
\hline 70 & 44 & $9,40 \pm 0,08$ & $8,36 \pm 0,05$ & $88,93^{\mathrm{a}} \pm 0,174$ \\
\hline 80 & 51 & $9,00 \pm 0,08$ & $6,00 \pm 0,12$ & $66,7^{\mathrm{b}} \pm 0,205$ \\
\hline 90 & 56 & $9,04 \pm 0,08$ & $4,00 \pm 0,10$ & $44,2 \pm 0,210$ \\
\hline 100 & 59 & $9,30 \pm 0,08$ & $3,00 \pm 0,10$ & $32,3 \pm 0,190$ \\
\hline 110 & 61 & $9,20 \pm 0,08$ & 0 & 0
\end{tabular}

*Means followed by identical letters indicate no significant difference at a $95 \%$ confidence level (Tukey test, $\mathrm{p}<0.05)$.

The viability of microencapsulated probiotics that have been exposed to thermal treatment relies on many factors, such as using an encapsulating technique that can be adapted to the matrixes to be used in the process [29].

Arepally and Goswami [21] studied the effects of air inlet temperature and Arabic gum concentration on spray-dried microcapsules of Lactobacillus Acidophilus (NCDC 016) and have obtained an initial viable cell count in all of their treatments, ranging from 10.81 to $11.36 \log \mathrm{CFU} / \mathrm{g}$ at a temperature of $130^{\circ} \mathrm{C}$. They have also noted that by increasing the air inlet temperature, cell viability would be reduced from 9.97 to $7.3 \log \mathrm{CFU} / \mathrm{g}$. This reduction in cell viability might have been caused due to injuries such as DNA and RNA denaturation, cell membrane dehydration, or cell rupture and collapse due to the sudden removal of water from inside the cells. The major drawback of the spray drying method for probiotic microencapsulation is the limited survival of the probiotics due to the mechanical stress and heat treatment involved [30].

In a study done by Nunes et al. [31], the viability of microparticles containing $L$. acidophilus La-5 (ML) and Bifidobacterium Bb-12 (MB) produced in different drying temperatures $\left(110\right.$ to $\left.140^{\circ} \mathrm{C}\right)$ was also negatively impacted by the increase in temperature. Similar results were also reported by Bustamante et al. [32] using chia seed mucilage extracted via spray-drying using different temperatures $\left(110\right.$ and $\left.140^{\circ} \mathrm{C}\right)$. Arslan et al. [33] reported that an increase in the ai inlet's temperature resulted in reduced viability and lower survivability rates of Saccharomyces cerevisiae var. boulardi. Fávaro-Trindade and Grosso [34] and Lian [35], reported that different microorganism strains might have different temperature tolerance thresholds for spray-drying. 
Table 3 describes the assays performed to prepare the inoculum of $L$. herveticus, the counting of live cells before and after spray-drying at $70^{\circ} \mathrm{C}$, and the survival rate of cells encapsulated on a matrix of gum Arabic-maltodextrin (1:1).

The number of probiotic cells was counted before and after the inoculums underwent the spray-drying process. During the inoculation of L. helveticus, cell counts of 9.40 and $9.04 \log$ CFU/g were found for assays 3 and 4, respectively. When using freeze-dried cells (Assay 6), an initial cell count of $10.3 \mathrm{log} \mathrm{CFU} / \mathrm{g}$ was found. The microcapsules found in assays 3,4 , and 6 , after spray-drying at $70^{\circ} \mathrm{C}$, displayed cell numbers above $8 \log \mathrm{CFU} / \mathrm{g}$, and were the ones with the highest survivability rates $(88.93,88.38$, and $90.48 \%$, respectively).

Table 3. Survival rate of encapsulated probiotic cells from different inoculum, after spray-drying at $70^{\circ} \mathrm{C}$.

\begin{tabular}{c|c|c|c} 
Assay & $\begin{array}{c}\text { Cell count before } \\
\text { drying } \\
(\mathbf{l o g} \text { UFC/g) }\end{array}$ & $\begin{array}{c}\text { Cell count after } \\
\text { drying } \\
(\mathbf{l o g} \mathbf{U F C} / \mathbf{g})\end{array}$ & $\begin{array}{c}\text { Survivability } \\
\text { rate } \\
(\boldsymbol{\%}) *\end{array}$ \\
\hline 1 - LB broth/24 h incubation & $8.30 \pm 0.08$ & $7.30 \pm 0.08$ & $87.95^{\mathrm{c}} \pm 0.169$ \\
\hline 2- LB broth/48 h incubation & $8.00 \pm 0.08$ & $6.00 \pm 0.12$ & $75.0^{\mathrm{d}} \pm 0.205$ \\
\hline 3- Culture split/LB broth/48 $\mathrm{h}$ & $9.40 \pm 0.08$ & $8.36 \pm 0.05$ & $88.93^{\mathrm{b}} \pm 0.174$ \\
\hline 4- MRS broth/60 h incubation & $9.04 \pm 0.08$ & $8.08 \pm 0.05$ & $89.38^{\mathrm{b}} \pm 0.069$ \\
\hline 5 - MRS broth/48 h incubation & $8.08 \pm 0.04$ & $7.04 \pm 0.03$ & $87.12^{\mathrm{c}} \pm 0.032$ \\
\hline 6 - Freeze dried cells/MRS broth & $10.30 \pm 0.08$ & $9.30 \pm 0.07$ & $90.48^{\mathrm{a}} \pm 0.049$
\end{tabular}

*Means followed by identical letters indicate no significant difference at a $95 \%$ confidence level (Tukey test, $\mathrm{p}<0.05)$.

Other than the minimal established number of viable cells added to a product, the encapsulating matrix is essential to guarantee that the cells are adequately protected during the drying process. Arslan et al. [33], when using gum Arabic as an encapsulating agent for spraydrying of $S$. cerevisiae, could obtain a survivability rate of $84 \%$. Nunes et al. [31] found a survivability rate of $84.61 \%$ for L. acidophilus when using gum Arabic and drying temperature of $130^{\circ} \mathrm{C}$. Lian [35] has also reported that gum Arabic could increase the survivability rate of Bifidobacterium after spray-drying at $130^{\circ} \mathrm{C}$.

\subsection{Microcapsule characteristics.}

The microcapsules of gum Arabic and maltodextrin $(1: 1)$, dried at $70^{\circ} \mathrm{C}$, were characterized regarding their water activity, humidity, and morphology. Furthermore, they were evaluated via differential scanning calorimetry (DSC) and submitted to thermogravimetric analysis (TG). Table 4 shows the results found for water activity and humidity of the microcapsules obtained from Assays 3 and 6 (Table 3), as they were the ones with the highest survivability rates after drying.

The microparticles' water activity and moisture are critical parameters on the stability of the probiotic cells. They may also play a role in the probiotic's viability during storage [36].

All the evaluated microparticles displayed $A_{w}$ values below 0.50 (Table 4). According to Fávaro-Trindade et al. [37] and Kumar et al. [38], this would positively impact the microcapsules' stability, for there is less water available be used in a biochemical reaction, thus, increasing their stability during storage. Regarding moisture, it can be noted that the samples remained at or below $13 \%$, something that is inversely proportional to the temperature used during the spray-drying process. However, since it is a probiotic that is being encapsulated, temperatures over $90^{\circ} \mathrm{C}$ greatly impact the microorganism's survivability. Furthermore, while the recommended humidity for microcapsules should be around 10\% [36], the probiotic's stability is greatly influenced by the product's sorption properties where the microcapsules will be added. 
Table 4. Spray-drying conditions and water activity $\left(\mathrm{A}_{\mathrm{w}}\right)$ and moisture $(\%)$ for probiotic microcapsules (Assays 3 and 6).

\begin{tabular}{c|c|c|c|c} 
Assay & $\begin{array}{c}\text { Air inlet } \\
\text { temperature } \\
\left({ }^{\mathbf{}} \mathbf{C}\right)\end{array}$ & $\begin{array}{c}\text { Air outlet } \\
\text { temperature } \\
\left({ }^{\mathbf{C}} \mathbf{C}\right)\end{array}$ & $\begin{array}{c}\text { Moisture* } \\
(\boldsymbol{\%})\end{array}$ & $\mathbf{A}^{*}{ }^{*}$ \\
\hline 3 & 70 & 44 & $13.20^{\mathrm{a}} \pm 0.10$ & $0.492^{\mathrm{a}} \pm 0.0020$ \\
\hline 6 & 70 & 44 & $13.30^{\mathrm{a}} \pm 0.10$ & $0.494^{\mathrm{a}} \pm 0.0017$ \\
\hline 3 & 80 & 51 & $12.70^{\mathrm{a}} \pm 0.78$ & $0.436^{\mathrm{d}} \pm 0.0006$ \\
\hline 6 & 80 & 51 & $12.50^{\mathrm{a}} \pm 0.89$ & $0.426^{\mathrm{e}} \pm 0.0225$ \\
\hline 3 & 90 & 56 & $10.63^{\mathrm{b}} \pm 0.06$ & $0.445^{\mathrm{c}} \pm 0.0006$ \\
\hline 6 & 90 & 56 & $10.60^{\mathrm{b}} \pm 0.17$ & $0.462^{\mathrm{b}} \pm 0.0239$ \\
\hline 3 & 100 & 59 & $10.67^{\mathrm{b}} \pm 0.06$ & $0.422^{\mathrm{e}} \pm 0.0010$ \\
\hline 6 & 100 & 59 & $10.57^{\mathrm{b}} \pm 0.06$ & $0.427^{\mathrm{e}} \pm 0.0025$ \\
\hline 3 & 110 & 61 & $9.40^{\mathrm{c}} \pm 0.10$ & $0.402^{\mathrm{f}} \pm 0.0060$ \\
\hline 6 & 110 & 61 & $9.33^{\mathrm{c}} \pm 0.15$ & $0.405^{\mathrm{f}} \pm 0.0002$
\end{tabular}

*Spray-drying operation conditions: flow rate $-0.09 \mathrm{~mL} / \mathrm{min}$; atomization pressure -0.08 to $0.12 \mathrm{bar}$; encapsulating agent gum Arabic (50\%), maltodextrin (50\%).

** Means followed by identical letters indicate no significant difference at a $95 \%$ confidence level (Tukey test, $\mathrm{p}<0.05)$.

Focusing on the $a_{\mathrm{w}}$ values found (Table 4), it can be observed that water activity decreases as the temperature increases. This might be caused due to gum Arabic's high affinity for water, as well as its highly ramified chain [39]. Arepally and Goswami [21] have observed something similar as well, as they have reported that the use of $10 \%$ of gum Arabic significantly reduced their microcapsule's aw (0.33) when compared to ones without gum Arabic (0.50) and dried at $130^{\circ} \mathrm{C}$. Nunes et al. [31] have encapsulated probiotics in a matrix composed of gum Arabic ( $8 \mathrm{~g})$, maltodextrin $(2 \mathrm{~g})$, glycerol $(1.9 \mathrm{~mL})$, and tween $80(0.1 \mathrm{~mL})$. They have observed an $\mathrm{a}_{\mathrm{w}}$ value of 0.289 in microcapsules containing L. acidophilus La-5e, and 0.228 when encapsulating Bifidobacterium Bb-12. Both microcapsule types were spray-dried at $110^{\circ} \mathrm{C}$

Figure 1 shows the thermogram found during the differential scanning calorimetry (DSC) of the maltodextrin-gum Arabic microcapsules with and without L. helveticus, dried at $70^{\circ} \mathrm{C}$.

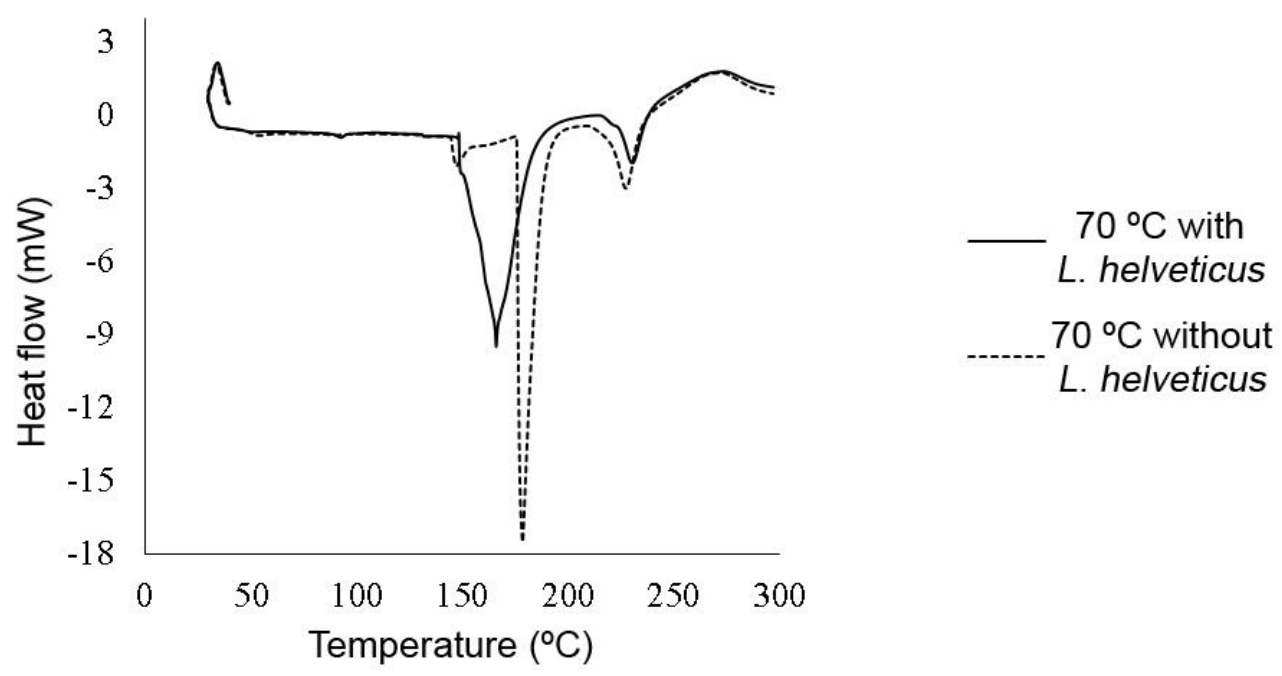

Figure 1. Thermogram of differential scanning calorimetry (DSC) of microcapsules made of gum Arabic maltodextrin, with and without $L$. helveticus, dried at $70^{\circ} \mathrm{C}$.

Observing Figure 1, it is possible to notice the presence of two endothermic peaks related to the melting temperature of the crystalline solid $\left(\mathrm{T}_{\mathrm{m}}\right)$. The peak at $165^{\circ} \mathrm{C}$ refers to the sample containing L. helveticus, while the one at $178^{\circ} \mathrm{C}$ comes from microcapsules without the 
probiotic. The addition of probiotic cells to the microcapsules drastically reduces the complex's melting point; however, this difference will not be relevant to the product in which the microcapsules will be added (chocolate).

Figure 2 presents thermograms found during thermogravimetric analysis of the microcapsules, with and without probiotic cells, spray-dried at $70^{\circ} \mathrm{C}$.

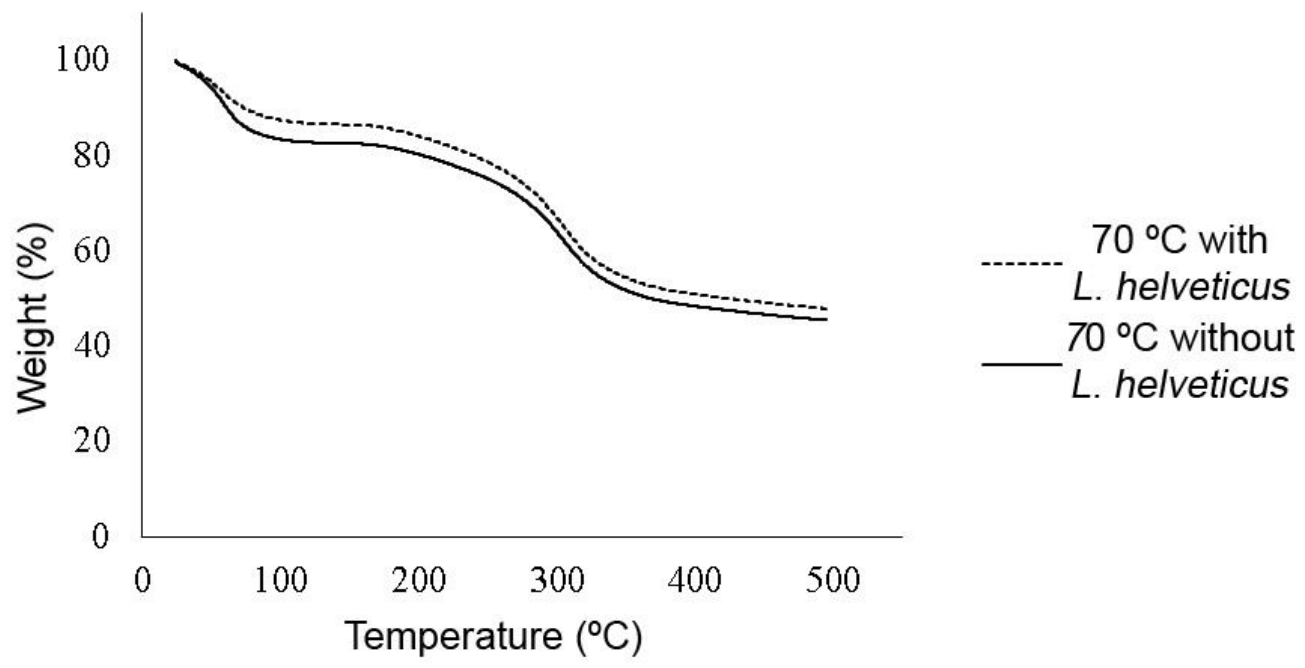

Figure 2. TGA thermogram for microcapsules made of gum Arabic - maltodextrin, with and without $L$. helveticus cells, spray-dried at $70^{\circ} \mathrm{C}$.

By observing Figure 2, it is possible to notice that the loss of mass behavior between the samples was very similar. The curves show an initial loss of approximately $15 \%$, related to the phosphate buffer's humidity, which corroborates with the results found via infra-red analysis (Table 4) in the range of 90 to $95^{\circ} \mathrm{C}$. Another loss of mass is also evident at about $50 \%$, related to the encapsulating agent and the probiotic cells, along with the temperature range of 160 to $350^{\circ} \mathrm{C}$. Above $350^{\circ} \mathrm{C}$, no other changes were observed. According to the studies were done by Nunes et al. [31], gum Arabic was considered the material with the highest thermal stability when compared to starches in general, for when modified starches replaced gum
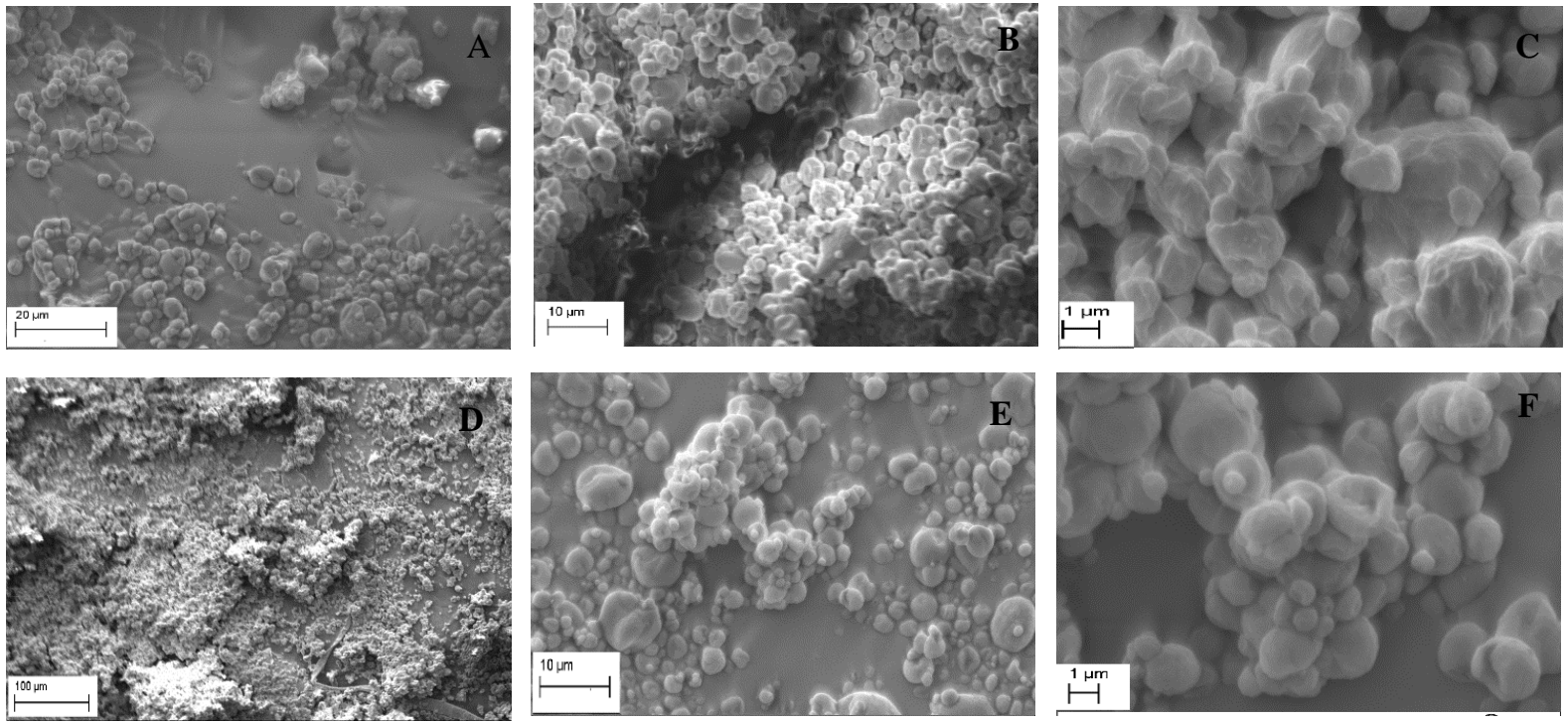

Figure 3. Electronic photomicrographs of gum Arabic - maltodextrin microcapsules containing L. helveticus (microcapsule clusters of $20 \mu \mathrm{m}-\mathbf{A} ; 10 \mu \mathrm{m}-\mathbf{B} ; 1 \mu \mathrm{m}-\mathbf{C})$ and without probiotic cells $(100 \mu \mathrm{m}-\mathbf{D} ; 10 \mu \mathrm{m}-$ $\mathbf{E} ; 1 \mu \mathrm{m}-\mathbf{F})$.

Arabic, the microparticle's thermal stability was reduced. 
The gum Arabic-maltodextrin microcapsules containing L. helveticus displayed a round shape, even particle size, no cracks, and few hollow pockets or flat areas (Figure 3), typical of spray-dried products [32]. These concavities or flattened areas usually come from high drying temperatures. They are related to the material used as a matrix [35].

It is also possible to see clusters of microparticles outside the spheres. When comparing the microcapsules containing probiotic cells with the ones without, they did not differ. It was possible to see the complete envelopment of the probiotic cells by the matrix (Figure 3), in pictures with a zoom of $20.000,10.000$, and 1.000 times, it was possible to note a honeycomblike pattern that traps the probiotic cells in the matrix, which suggests the existence of some form of physical protection for the cells by the encapsulating materials (gum Arabic maltodextrin).

The particle's average size for the ones containing probiotic cells and the ones without were $2.60 \mu \mathrm{m}( \pm 0.60)$ and $3.04 \mu \mathrm{m}( \pm 0.81)$, respectively. According to Kurozawa, Park, and Hubinger [40], higher concentrations of encapsulating agents promote an increase in particle size. Still, it is worth noting that the microparticles obtained via spray-drying had a small size and an even, spherical shape, which might help its incorporation on different food products due to the small surface tension between the microparticle and the food matrix, allowing for better fluidity and flow for the material [41].

\section{Conclusions}

This study presents a simple method for encapsulating the probiotic bacteria Lactobacillus helveticus in gum Arabic - maltodextrin microparticles via spray-drying. The optimization of the process and formulation parameters resulted in the production of novel probiotic microparticles with preserved stability and viability of probiotic cells above the minimum level of $10^{7} \mathrm{CFU} / \mathrm{g}$ at point of delivery, after microencapsulation. Also, the conditions and composition used in the present study created microparticles with acceptable physicochemical properties for further incorporation into food products.

\section{Funding}

This study was financed by CAPES, Brazil [Financial Code 001].

\section{Acknowledgments}

The authors thank the National Council for Scientific and Technological Development (CNPq), Coordination for the Improvement of Higher Education Personnel (CAPES), and Research Support Foundation of the State of Rio Grande do Sul (FAPERGS).

\section{Conflicts of Interest}

The authors declare no conflict of interest.

\section{References}

1. Liang, X.; Lv, Y.; Zhang, Z.; Yi, H.; Liu, T.; Li, R.; Yu, Z.; Zhang, L. Study on intestinal survival and cholesterol metabolism of probiotics. LWT 2020, 124, 109132, https://doi.org/10.1016/j.lwt.2020.109132.

2. Hojjati, M.; Behabahani, B.A.; Falah, F. Aggregation, adherence, anti-adhesion and antagonistic activity properties relating to surface charge of probiotic Lactobacillus brevis gp104 against Staphylococcus aureus. Microb. Pathog. 2020, 147, 104420, https://doi.org/10.1016/j.micpath.2020.104420. 
3. Kuerman, M.; Bao, Y.; Guo, Y.; Guo, M. Effects of prebiotic carbohydrates on the growth promotion and cholesterol-lowering abilities of compound probiotics in vitro. LWT 2020, 118, 108703, https://doi.org/10.1016/j.lwt.2019.108703.

4. Vasiee, A.; Falah, F.; Behbahani, B.A.; Tabatabaee-yazdi, F. Probiotic characterization of Pediococcus strains isolated from Iranian cereal-dairy fermented product: Interaction with pathogenic bacteria and the enteric cell line Caco-2. J. Biosci. Bioeng. 2020, 130, 471-479, https://doi.org/10.1016/j.jbiosc.2020.07.002.

5. Mousavi Khaneghah, A.; Abhari, K.; Eş, I.; Soares, M.B.; Oliveira, R.B.A.; Hosseini, H.; Rezaei, M.; Balthazar, C.F.; Silva, R.; Cruz, A.G.; Ranadheera, C.S.; Sant'Ana, A.S. Interactions between probiotics and pathogenic microorganisms in hosts and foods: A review. Trends Food Sci. Technol. 2020, 95, 205-218, https://doi.org/10.1016/j.tifs.2019.11.022.

6. Evivie, S.E.; Abdelazez, A.; Li, B.; Bian, X.; Li, W.; Du, J.; Huo, G.; Liu, F. In vitro organic acid production and in vivo food pathogen suppression by probiotic S. thermophilus and L. bulgaricus. Front. Microbiol. 2019, 10, 782, https://doi.org/10.3389/fmicb.2019.00782.

7. Soares, M.B.; Martinez, R.C.R.; Pereira, E.P.R.; Balthazar, C.F.; Cruz, A.G.; Ranadheera, C.S.; Sant'Ana, A.S. The resistance of Bacillus, Bifidobacterium, and Lactobacillus strains with claimed probiotic properties in different food matrices exposed to simulated gastrointestinal tract conditions. Food Res. Int. 2019, 125, 108542, https://doi.org/10.1016/j.foodres.2019.108542.

8. Ku, S.; Yang, S.; Lee, H.H.; Choe, D.; Johnston, T.V.; Ji, G.E.; Park, M.S. Biosafety assessment of Bifidobacterium animalis subsp. lactis AD011 used for human consumption as a probiotic microorganism. Food Control 2020, 117, 106985, https://doi.org/10.1016/j.foodcont.2019.106985.

9. Liu, Z.; Bhandari, B.; Zhang, M. Incorporation of probiotics (Bifidobacterium animalis subsp. Lactis) into 3D printed mashed potatoes: Effects of variables on the viability. Food Res. Int. 2020, 128, 108795, https://doi.org/10.1016/j.foodres.2019.108795.

10. Chugh, B.; Kamal-Eldin, A. Bioactive compounds produced by probiotics in food products. Current Opinion in Food Science 2020, 32, 76-82, https://doi.org/10.1016/j.cofs.2020.02.003.

11. Naissinger da Silva, M.; Tagliapietra, B.L.; Richards, N.S.P.d.S. Encapsulation, storage viability, and consumer acceptance of probiotic butter. LWT 2020, 110536, https://doi.org/10.1016/j.lwt.2020.110536.

12. Mohammadi, R.; Mortazavian, A.M.; Khosrokhavar, R.; da Cruz, A.G. Probiotic ice cream: viability of probiotic bacteria and sensory properties. Ann. Microbiol. 2011, 61, 411-424, https://doi.org/10.1007/s13213-010-0188-z.

13. Rodrigues, F.J.; Cedran, M.F.; Bicas, J.L.; Sato, H.H. Encapsulated probiotic cells: Relevant techniques, natural sources as encapsulating materials and food applications - A narrative review. Food Res. Int. 2020, 137, 109682, https://doi.org/10.1016/j.foodres.2020.109682.

14. de Araújo Etchepare, M.; Nunes, G.L.; Nicoloso, B.R.; Barin, J.S.; Moraes Flores, E.M.; de Oliveira Mello, R.; Ragagnin de Menezes, C. Improvement of the viability of encapsulated probiotics using whey proteins. LWT 2020, 117, 108601, https://doi.org/10.1016/j.lwt.2019.108601.

15. Arepally, D.; Reddy, R.S.; Goswami, T.K. Studies on survivability, storage stability of encapsulated spray dried probiotic powder. Current Research in Food Science 2020, 3, 235-242, https://doi.org/10.1016/j.crfs.2020.09.001.

16. Hadzieva, J.; Mladenovska, K.; Simonoska Crcarevska, M.; Glavaš Dodov, M.; Dimchevska, S.; Geškovski, N.; Grozdanov, A.; Popovski, E.; Petruševski, G.; Chachorovska, M. Lactobacillus casei encapsulated in soy protein isolate and alginate microparticles prepared by spray drying. Food Technol. Biotechnol. 2017, 55, 173-186, https://doi.org/10.17113/ftb.55.02.17.4991.

17. Peighambardoust, S.H.; Golshan Tafti, A.; Hesari, J. Application of spray drying for preservation of lactic acid starter cultures: a review. Trends Food Sci. Technol. 2011, 22, 215-224, https://doi.org/10.1016/j.tifs.2011.01.009.

18. Silva, V.M.; Vieira, G.S.; Hubinger, M.D. Influence of different combinations of wall materials and homogenisation pressure on the microencapsulation of green coffee oil by spray drying. Food Res. Int. 2014, 61, 132-143, https://doi.org/10.1016/j.foodres.2014.01.052.

19. Premi, M.; Sharma, H.K. Effect of different combinations of maltodextrin, gum Arabic and whey protein concentrate on the encapsulation behavior and oxidative stability of spray dried drumstick (Moringa oleifera) oil. Int. J. Biol. Macromol. 2017, 105, 1232-1240, https://doi.org/10.1016/j.ijbiomac.2017.07.160.

20. Paula, D.d.A.; Martins, E.M.F.; Costa, N.d.A.; de Oliveira, P.M.; de Oliveira, E.B.; Ramos, A.M. Use of gelatin and gum Arabic for microencapsulation of probiotic cells from Lactobacillus plantarum by a dual process combining double emulsification followed by complex coacervation. Int. J. Biol. Macromol. 2019, 133, 722-731, https://doi.org/10.1016/j.ijbiomac.2019.04.110.

21. Arepally, D.; Goswami, T.K. Effect of inlet air temperature and gum Arabic concentration on encapsulation of probiotics by spray drying. LWT 2019, 99, 583-593, https://doi.org/10.1016/j.lwt.2018.10.022.

22. Liu, H.; Cui, S.W.; Chen, M.; li, Y.; Liang, R.; Xu, F.; Zhong, F. Protective approaches and mechanisms of microencapsulation to the survival of probiotic bacteria during processing, storage and gastrointestinal digestion: A review. Crit. Rev. Food Sci. Nutr. 2019, 59, 2863-2878, https://doi.org/10.1080/10408398.2017.1377684. 
23. Taheri, A.; Jafari, S.M. 18 - Nanostructures of gums for encapsulation of food ingredients. In Biopolymer Nanostructures for Food Encapsulation Purposes, Jafari, S.M., Ed. Academic Press: 2019, https://doi.org/10.1016/B978-0-12-815663-6.00018-5.

24. Zhou, T.; Huo, R.; Kwok, L.-Y.; Li, C.; Ma, Y.; Mi, Z.; Chen, Y. Effects of applying Lactobacillus helveticus H9 as adjunct starter culture in yogurt fermentation and storage. J. Dairy Sci. 2019, 102, 223-235, https://doi.org/10.3168/jds.2018-14602.

25. Giacometti Cavalheiro, F.; Parra Baptista, D.; Domingues Galli, B.; Negrão, F.; Nogueira Eberlin, M.; Lúcia Gigante, M. High protein yogurt with addition of Lactobacillus helveticus: Peptide profile and angiotensinconverting enzyme ACE-inhibitory activity. Food Chem. 2020, 333, 127482, https://doi.org/10.1016/j.foodchem.2020.127482.

26. Brasil. Anvisa. Resolução n 2, de 7 de janeiro de 2002. Aprova o Regulamento Técnico de substâncias bioativas e probióticos isolados com alegação de propriedades funcional e ou de saúde. Diário Oficial da República Federativa do Brasil. Brasília, 09 jan. 2002. Available online: http://portal.anvisa.gov.br (accessed on 03 June 2017).

27. Silva, M.P.; Tulini, F.L.; Marinho, J.F.U.; Mazzocato, M.C.; De Martinis, E.C.P.; Luccas, V.; FavaroTrindade, C.S. Semisweet chocolate as a vehicle for the probiotics Lactobacillus acidophilus LA3 and Bifidobacterium animalis subsp. lactis BLC1: Evaluation of chocolate stability and probiotic survival under in vitro simulated gastrointestinal conditions. LWT 2017, 75, 640-647, https://doi.org/10.1016/j.lwt.2016.10.025.

28. Dutcosky, S. D. Análise sensorial de alimentos. Curitiba, PR: Champagnat, 2019, 531.

29. Vemmer, M.; Patel, A.V. Review of encapsulation methods suitable for microbial biological control agents. Biol. Control 2013, 67, 380-389, https://doi.org/10.1016/j.biocontrol.2013.09.003.

30. Behboudi-Jobbehdar, S.; Soukoulis, C.; Yonekura, L.; Fisk, I. Optimization of Spray-Drying Process Conditions for the Production of Maximally Viable Microencapsulated L. acidophilus NCIMB 701748. Drying Technol. 2013, 31, 1274-1283, https://doi.org/10.1080/07373937.2013.788509.

31. Nunes, G.L.; Motta, M.H.; Cichoski, A.J.; Wagner, R.; Muller, É.I.; Codevilla, C.F.; Silva, C.d.B.d.; Menezes, C.R.d. Encapsulation of Lactobacillus acidophilus La-5 and Bifidobacterium Bb-12 by spray drying and evaluation of its resistance in simulated gastrointestinal conditions, thermal treatments and storage conditions. Ciência Rural 2018, 48, https://doi.org/10.1590/0103-8478cr20180035.

32. Bustamante, M.; Oomah, B.D.; Rubilar, M.; Shene, C. Effective Lactobacillus plantarum and Bifidobacterium infantis encapsulation with chia seed (Salvia hispanica L.) and flaxseed (Linum usitatissimum L.) mucilage and soluble protein by spray drying. Food Chem. 2017, 216, 97-105, https://doi.org/10.1016/j.foodchem.2016.08.019.

33. Arslan, S.; Erbas, M.; Tontul, I.; Topuz, A. Microencapsulation of probiotic Saccharomyces cerevisiae var. boulardii with different wall materials by spray drying. LWT 2015, 63, 685-690, https://doi.org/10.1016/j.lwt.2015.03.034.

34. Fávaro-Trindade, C.S.; Grosso, C.R.F. Microencapsulation of L. acidophilus (La-05) and B. lactis (Bb-12) and evaluation of their survival at the $\mathrm{pH}$ values of the stomach and in bile. J. Microencaps. 2002, 19, 485494, https://doi.org/10.1080/02652040210140715.

35. Lian, W.-C.; Hsiao, H.-C.; Chou, C.-C. Survival of bifidobacteria after spray-drying. Int. J. Food Microbiol. 2002, 74, 79-86, https://doi.org/10.1016/s0168-1605(01)00733-4.

36. Guerin, J.; Petit, J.; Burgain, J.; Borges, F.; Bhandari, B.; Perroud, C.; Desobry, S.; Scher, J.; Gaiani, C. Lactobacillus rhamnosus GG encapsulation by spray-drying: Milk proteins clotting control to produce innovative matrices. J. Food Eng. 2017, 193, 10-19, https://doi.org/10.1016/j.jfoodeng.2016.08.008.

37. Favaro-Trindade, C.S.; Santana, A.S.; Monterrey-Quintero, E.S.; Trindade, M.A.; Netto, F.M. The use of spray drying technology to reduce bitter taste of casein hydrolysate. Food Hydrocolloids 2010, 24, 336-340, https://doi.org/10.1016/j.foodhyd.2009.10.012.

38. R.G. Kumar, L.; Chatterjee, N.S.; Tejpal, C.S.; Vishnu, K.V.; Anas, K.K.; Asha, K.K.; Anandan, R.; Mathew, S. Evaluation of chitosan as a wall material for microencapsulation of squalene by spray drying: Characterization and oxidative stability studies. Int. J. Biol. Macromol. 2017, 104, 1986-1995, https://doi.org/10.1016/j.ijbiomac.2017.03.114.

39. Sanchez, C.; Nigen, M.; Mejia Tamayo, V.; Doco, T.; Williams, P.; Amine, C.; Renard, D. Acacia gum: History of the future. Food Hydrocolloids 2018, 78, 140-160, https://doi.org/10.1016/j.foodhyd.2017.04.008.

40. Kurozawa, L.E.; Park, K.J.; Hubinger, M.D. Effect of maltodextrin and gum Arabic on water sorption and glass transition temperature of spray dried chicken meat hydrolysate protein. J. Food Eng. 2009, 91, 287296, https://doi.org/10.1016/j.jfoodeng.2008.09.006.

41. Chen, M.J.; Chen, K.N. Applications of probiotic encapsulation in dairy products. Encapsulation and controlled release technologies in food systems 2007, 83-112. 